\title{
Investigating the Correlation between Some of the Properties of Plasma Nitrided AISI 316L Stainless Steel
}

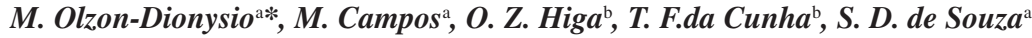 \\ aphysics Department, Federal University of São Carlos - UFSCar, \\ CEP 13565-905, São Carlos, SP, Brazil \\ ${ }^{\mathrm{b}}$ Biotechnology Center, Energy and Nuclear Research Institute - IPEN, \\ CEP 05508-000, São Paulo, SP, Brazil
}

Received: September 27, 2012; Revised: February 19, 2013

\begin{abstract}
When AISI 316L stainless steels are submitted to the nitriding process at temperatures lower than $450{ }^{\circ} \mathrm{C}$, a high nitrogen content expanded austenite phase is formed, which shows higher hardness and higher pitting corrosion resistance compared to the untreated material. As a result, this material becomes adequate for biomedical application. The conditions of the nitriding technique, such as gas mixture, pressure, time and temperature, play an important role in some properties of the modified layer, including: thickness, hardness and $\mathrm{N}$ concentration along the layer. This paper explores a set of six samples of AISI 316L, nitrided at different times and temperatures, whose properties show important differences. The aim of this research is to investigate the correlation between the nitrided layer thickness (in the range of 0.77 to $11 \mu \mathrm{m}$ ) with both X-ray patterns characteristics and hardness measurements, which used two distinct loads. The results of this study show that: whereas the $3.6 \mathrm{gf}$ load was suitable to measure the real hardness for four of the nitrided layers showing thickness $\geq 2.9 \mu \mathrm{m}$, the $50 \mathrm{gf}$ load measured a substrate contribution, probably even for the highest thickness, $11 \mu \mathrm{m}$. Moreover, analyzing different reflections of the X-ray patterns showed evidence of the clear consistency between the X-Ray depths and the nitrided layer thicknesses: if the layer thickness is lower than the penetration depth of X-rays, two phases (austenite and expanded substrate) are present. If the layer thickness is higher, only the austenite is observed. Finally, concerning the citotoxicity property, all the samples, nitrided or not, were approved in the test for biocompatibility, indicating their potential use for biomedical applications.
\end{abstract}

Keywords: AISI 316 L, plasma nitriding, layer thickness, hardness, $X$ - ray diffraction, citotoxicity

\section{Introduction}

The practice of using metals and alloys to repair or replace human body parts is now well established. Two of the most important parameters in determining the suitability of a material for biomedical applications are its biocompatibility and corrosion resistance ${ }^{1-3}$. Regarding these two parameters, pure titanium appears to be almost the perfect biomaterial, but it is still essential to provide high strength or ductility for many surgical and dental applications. Hence, materials such as stainless steels ${ }^{2-4}$, particularly ASTM F138 and AISI 316L, have been used as alternative materials. The corrosion resistance and hardness of these alloys are inadequate for this application, but if they are submitted to an adequate nitriding process, these properties can be improved ${ }^{5-8}$. When nitriding is performed at temperatures lower than $450{ }^{\circ} \mathrm{C}$ a high nitrogen content expanded austenite phase is formed, which shows higher hardness and higher pitting corrosion resistance compared to the untreated material ${ }^{7-10}$. The conditions of the nitriding technique (gas mixture, pressure, time and temperature) play an important role in the characteristic of the modified layer ${ }^{7,11,12}$, as thickness, hardness and $\mathrm{N}$ concentration along the layer. Although extensive research has been carried out

*e-mail: maristolzon@hotmail.com on plasma nitriding of stainless steels, researchers have not explored in much detail the correlation between both, the nitrided layer thickness and hardness measurements or X-ray patterns characteristics. The aim of this work is to cover this aspect adequately. In order to produce nitrided layers with different characteristics, six samples of AISI 316L austenitic stainless steel were nitrided at different times ( 3 and $5 \mathrm{~h}$ ) and temperatures $\left(350{ }^{\circ} \mathrm{C}, 400{ }^{\circ} \mathrm{C}\right.$ and $\left.450{ }^{\circ} \mathrm{C}\right)$. Results of nitrided layers thickness, hardness, X-ray diffraction patterns and the correlation between them are presented here. Some results of citotoxicity are also reported.

\section{Material and Methods}

Samples: In this study, AISI 316L stainless steel produced by Villares Metals was used. Its chemical composition (only elements with wt.\% $>0.10$ ) is: $16.1 \pm$ $0.2 \mathrm{Cr}, 10.1 \pm 0.1 \mathrm{Ni}, 2.1 \pm 0.1 \mathrm{Mo}, 1.80 \pm 0.02 \mathrm{Mn}, 0.37$ $\pm 0.05 \mathrm{Si}, 0.31 \pm 0.04 \mathrm{Cu}, 0.180 \pm 0.004 \mathrm{~W}, 0.13 \pm 0.01$ Co, balance Fe. The samples (diameter: $19.70 \pm 0.05 \mathrm{~mm}$, thickness: $3.85 \pm 0.05 \mathrm{~mm}$ ) were sanded using sandpaper from 220 to 1200 mesh, polished with alumina ( 0.3 and $1 \mu \mathrm{m})$, cleaned ultrasonically in an acetone bath, and finally air-dried. Next, they were plasma nitrided in cold wall 
equipment using d.c. power supply. The gas composition was $80 \% \mathrm{H}_{2}-20 \% \mathrm{~N}_{2}$, at a pressure of about 6 torr. The voltage and current density were adjusted to maintain the cathode temperature (or nitriding temperature). The temperature was measured using an alumel-chromel (type K) long rod thermocouple placed underneath the sample. Three different temperatures $\left(350^{\circ} \mathrm{C}, 400{ }^{\circ} \mathrm{C}\right.$ and $\left.450{ }^{\circ} \mathrm{C}\right)$ were used at two different nitriding times, 3 and $5 \mathrm{~h}$.

Scanning Electron Microscopy: A section of the samples were observed using a JEOL scanning electron microscope, JSM - 5800 LV model in order to measure the depth of the nitrided layer.

Hardness: The surface hardness was measured using a Leica microhardness tester (model VMHT-MOT) with a Vickers indenter at a load of $50 \mathrm{gf}$. The hardness was measured at about 20 different positions along the diameter, aiming at achieving more representative results. Each position was repeated three times at a distance of $20 \pm 2 \mu \mathrm{m}$ from one to the other. Other measurements of hardness, which were done along the diameter, equally spaced of $0.25 \mathrm{~mm}$, were done using a Fischerscope H100V microhardness tester with a Vickers indenter at a load of $35 \mathrm{mN}$ ( 3.6 gf). Due to the low load used in the last one, a special computational routine, which was developed for treating similar data, was used on the data treatment ${ }^{13}$.

X- ray diffraction: $X$-ray diffraction patterns of untreated and nitrided samples were obtained using a Rigaku (Geigerflex model) diffractometer, $\mathrm{Cu} \mathrm{K} \alpha$ radiation
( $\lambda=0.154056 \mathrm{~nm})$. The conditions were: $2 \theta$ scan step $0.02^{\circ}$, ranging from $30^{\circ}$ to $100^{\circ}, 2 \mathrm{~s}$ counting time.

Cytotoxicity test: Following the guidelines of ISO $10993-5^{[14]}$, the cytotoxicity test was performed in culture microplates seeded with $\mathrm{CHO}$ cells and sample extracts diluted from 100 to $6.25 \%^{[15]}$. The microplates were incubated for $72 \mathrm{~h}$ at $37{ }^{\circ} \mathrm{C}$ in a humidified $5 \% \mathrm{CO}_{2}$ atmosphere. The cell viability was measured by adding $20 \mu \mathrm{L}$ of MTS/PMS (20:1) solution and incubated for $2 \mathrm{~h}$ in the $\mathrm{CO}_{2}$ incubator. The microplates were read in a spectrophotometer reader at $495 \mathrm{~nm}$. The results were compared with a negative control of titanium and a positive control of phenol $0.3 \%$ in saline solution. The Inhibitory Concentration for $50 \%$ of cell viability was taken from graphs.

\section{Results and Discussions}

\subsection{Nitrided layer thickness and hardness measurements}

Figure 1a, b show the Scanning Electronic Microscopy (SEM) micrographs of the sample nitrided at $450{ }^{\circ} \mathrm{C}$ for $5 \mathrm{~h}$ to illustrate the measurements of nitrided layer thickness t. The arithmetic mean value of 6 measurements, which were done for all the nitrided samples, are shown in the $3^{\text {rd }}$ column of Table 1 . Based on this values, one can see

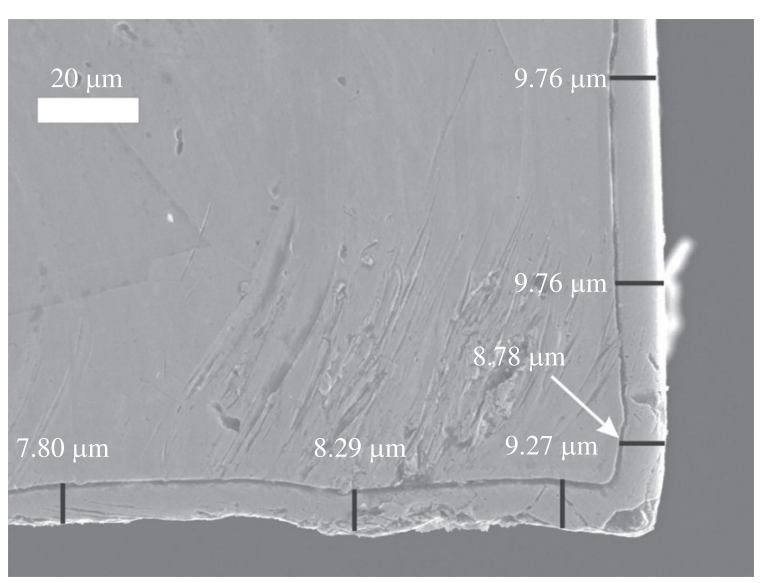

(a)

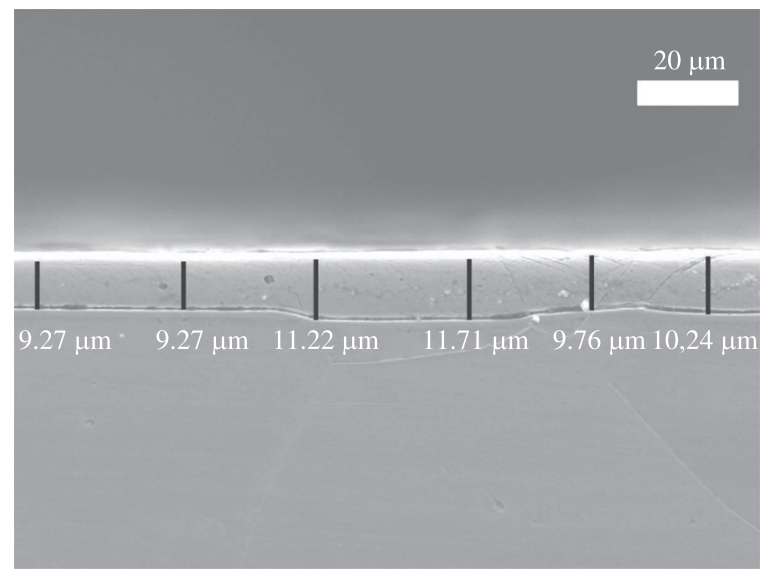

(b)

Figure 1. SEM micrographs of sample nitrided at $450{ }^{\circ} \mathrm{C}$, for $5 \mathrm{~h}$ (a) near the edge, (b) in the central region.

Table 1. Some characteristics and properties of the nitrided layers: nitrided layer thickness (t), mean value of hardness and mean value of penetration depth (p) of the Vickers indenter.

\begin{tabular}{|c|c|c|c|c|c|c|}
\hline \multirow{2}{*}{$\begin{array}{c}\text { Temperature } \\
\left({ }^{\circ} \mathbf{C}\right)\end{array}$} & \multirow{2}{*}{$\begin{array}{l}\text { Time } \\
\text { (h) }\end{array}$} & \multirow[b]{2}{*}{$\mathbf{t}(\mu \mathrm{m})$} & \multicolumn{2}{|c|}{ load (50 gf) } & \multicolumn{2}{|c|}{ load (3.6 gf) } \\
\hline & & & $\begin{array}{l}\text { Hardness } \\
\mathrm{HV}_{0.05 \times} 10\end{array}$ & $\begin{array}{c}p(\mu \mathrm{m}) \\
\text { (indentation depth) }\end{array}$ & $\begin{array}{c}\text { Hardness } \\
\mathrm{HV}_{0.0036 \times} 10\end{array}$ & $\begin{array}{c}p(\mu \mathrm{m}) \\
\text { (indentation depth) }\end{array}$ \\
\hline \multirow{2}{*}{350} & 3 & $0.77 \pm 0.04$ & $39.6 \pm 7.0$ & $2.23 \pm 0.15$ & $77 \pm 11$ & $0.45 \pm 0.02$ \\
\hline & 5 & $1.0 \pm 0.1$ & $44.5 \pm 5.1$ & $2.08 \pm 0.08$ & $79 \pm 12$ & $0.46 \pm 0.03$ \\
\hline \multirow{2}{*}{400} & 3 & $2.9 \pm 0.1$ & $49.5 \pm 6.7$ & $1.97 \pm 0.09$ & $172 \pm 18$ & $0.37 \pm 0.04$ \\
\hline & 5 & $3.5 \pm 0.4$ & $67 \pm 10$ & $1.67 \pm 0.15$ & $175 \pm 17$ & $0.34 \pm 0.01$ \\
\hline \multirow{2}{*}{450} & 3 & $7.6 \pm 0.2$ & $117 \pm 10$ & $1.35 \pm 0.13$ & $179 \pm 20$ & $0.34 \pm 0.01$ \\
\hline & 5 & $11 \pm 1$ & $123 \pm 10$ & $1.28 \pm 0.09$ & $162 \pm 31$ & $0.40 \pm 0.01$ \\
\hline \multicolumn{3}{|c|}{ Untreated } & \multicolumn{2}{|c|}{$243 \pm 40$} & \multicolumn{2}{|c|}{$298 \pm 19$} \\
\hline
\end{tabular}


that thickness increases up to a factor of 9.5 and 11 in the temperature interval $\left(350{ }^{\circ} \mathrm{C}\right.$ to $\left.450{ }^{\circ} \mathrm{C}\right)$ for both $\mathrm{t}=3 \mathrm{~h}$ and $\mathrm{t}=5 \mathrm{~h}$, respectively. It seems to indicate that the thickness of the nitrided layer is primarily a function of temperature ${ }^{12,16}$. Similar behavior was observed in a previous study on AISI 304 , where the thickness increased from 2-3 to $30 \mu \mathrm{m}$ for practically the same temperature interval $\left(350{ }^{\circ} \mathrm{C}\right.$ to $\left.460{ }^{\circ} \mathrm{C}\right)^{16}$.

Concerning hardness measurements, Figure $2 \mathrm{a}, \mathrm{b}$ illustrate the hardness measurements for both loads on the surface of the samples nitrided for $3 \mathrm{~h}$. The mean values, which are represented by a dashed line in the Figures 2, are shown in the $4^{\text {th }}$ and $6^{\text {th }}$ columns of Table 1 for all the samples. For the untreated sample, this value is $\mathbf{2 4 3} \pm \mathbf{4 0}$ $\mathbf{H V}_{\mathbf{0 . 0 5}}$ and $298 \pm \mathbf{1 9} \mathbf{H V}_{\mathbf{0 . 0 0 3 6}}$, for loads of 50 and $3.6 \mathrm{gf}$, respectively.

The penetration depth $\mathbf{p}$ of the Vickers indenter was estimated from the length of the diagonal line across the indent marked on each sample. The mean values are presented in the $5^{\text {th }}$ and $7^{\text {th }}$ columns. Figure $3 a, b$ depict hardness values as a function of the ratio between penetration depth $\mathbf{p}$ and nitrided layer thickness $\mathbf{t}$, for both load, 3.6 gf and 50 gf, respectively. In these figures, the position of $\mathbf{p} / \mathbf{t}=1 / 7^{[17]}$, which is the ratio indicated to avoid the influence of substrate, is marked as a dashed line. On the left of this line in Figure 3a, there is compatibility among the hardness values, which were measured for the four samples, which were prepared at $400{ }^{\circ} \mathrm{C}$ and $450{ }^{\circ} \mathrm{C}$. So, the values showed on the left of the dashed line in Figure $3 \mathrm{a}$ seem to represent essentially real hardness of the nitrided layers, which reached an improvement of a factor by 6 times compared to the substrate. This result is compatible with some previous, when the authors found hardness value of $17 \mathrm{GPa}(\sim 1733 \mathrm{HV})^{18}$.

However, in Figure $3 \mathrm{a}$, for the $350^{\circ} \mathrm{C}$ samples, which show thinner layer, there is some substrate contribution. Such contribution is much more significant for all the measurements in Figure $3 b$, where practically all the $\mathbf{p} / \mathbf{t}$ values are on the right of the dashed line. Nevertheless, even at the highest load (50 gf), for the less favorable sample

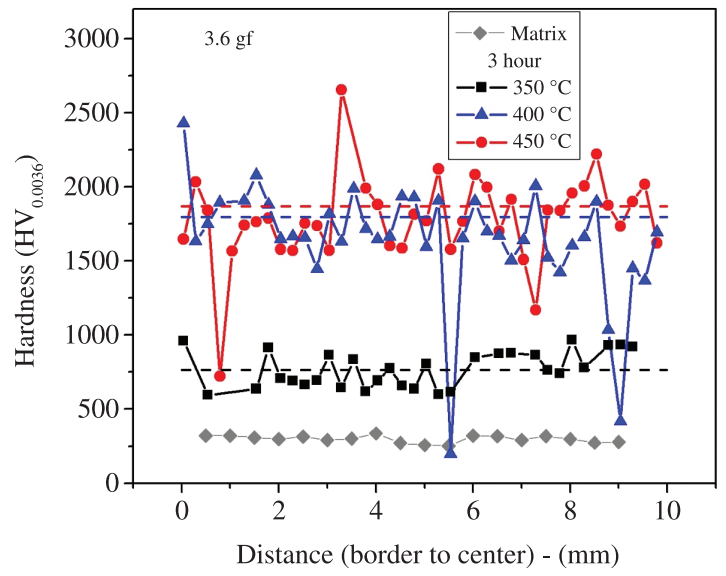

(a)

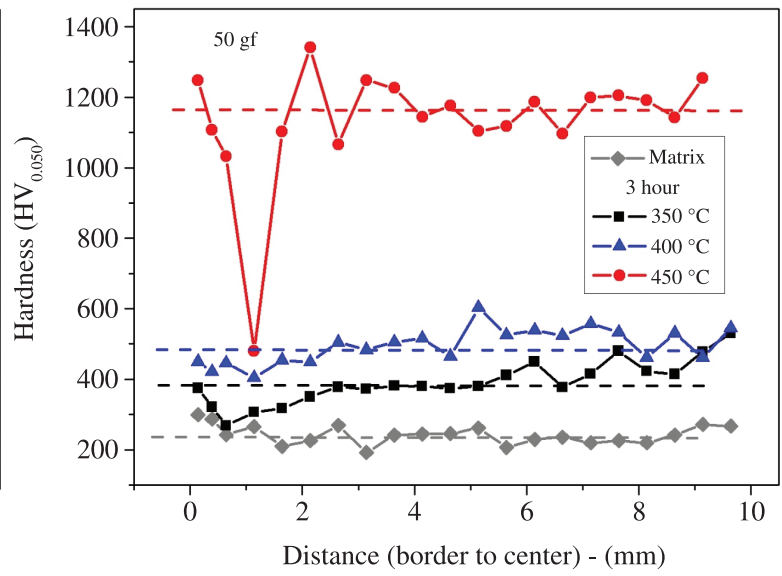

(b)

Figure 2. Hardness measurements on surface samples nitrided for $3 \mathrm{~h}$, from the border to the center, at different temperatures, using different loads (a) $3.6 \mathrm{gf}$, (b) 50 gf.

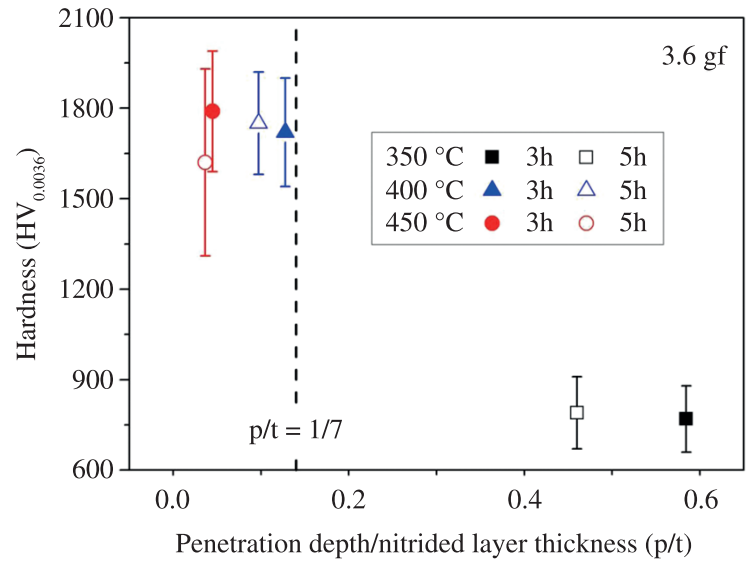

(a)

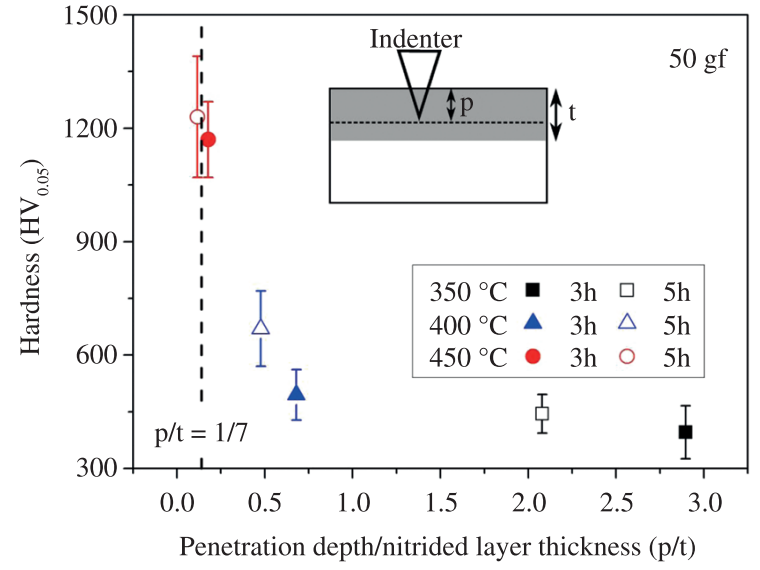

(b)

Figure 3. Hardness value as function of ratio between penetration depth $\mathrm{p}$ and nitrided layer thickness $\mathrm{t}$, using different loads (a) $3.6 \mathrm{gf}$ (b) and $50 \mathrm{gf}$. 
(3h), the hardness is about $160 \%$ of the one measured for the substrate.

\subsection{X-ray Diffraction (XRD)}

The X-ray diffraction pattern for the AISI 316L samples before and after nitriding for $3 \mathrm{~h}$ are shown in Figure 4. All the samples nitrided show the expanded austenite peaks, which are broader and shifted to lower diffraction angles, when compared to the austenitic substrate.

The samples nitrided at $350^{\circ} \mathrm{C}$ clearly show the substrate peaks, which apparently seems not to occur for $400{ }^{\circ} \mathrm{C}$ and $450{ }^{\circ} \mathrm{C}$. However, this is not true and we can obtain relevant information about the $\mathrm{N}$ concentration, if we analyze, for example, a reflection where there are different ratios between the X-ray depth $\mathbf{d}$ and the layer thickness $\mathbf{t}(\mathbf{d} / \mathbf{t})$. For this purpose, let us consider two different reflections.

First, let us take the (111) reflection, at $43.7^{\circ}$ position, for example. A zoom of this peak is shown in Figure 5a, b, for the samples nitrided at 3 and 5 h. If $99 \%$ absorption of $\mathrm{X}$-ray in the sample is considered, in this configuration $\Theta-2 \Theta$, the $\mathrm{X}$-ray penetration depth $\mathbf{d}$ is approximately $4 \mu \mathrm{m}^{19}$. As the ratio $\mathbf{d} / \mathbf{t} \leq 0.52$ for $450{ }^{\circ} \mathrm{C}$ and $\mathbf{d} / \mathbf{t} \geq 4$ for $350^{\circ} \mathrm{C}$, the $\gamma(111)$ intensity is negligible for the first sample and very significant for the last one. On the other hand, for $400{ }^{\circ} \mathrm{C}$, the thickness values are compatible (whitin the measurement precision) for 3 and $5 \mathrm{~h}$ and are also close to d. Because of this, the $\gamma(111)$ intensity is quite small for both samples, 3 and $5 \mathrm{~h}$.

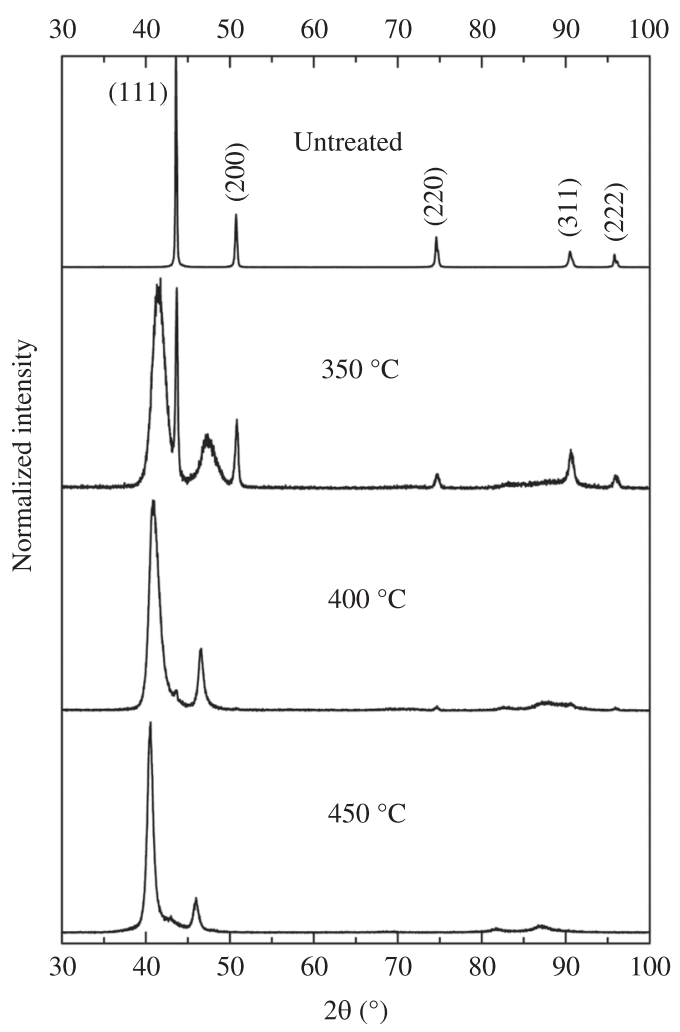

Figure 4. X-ray diffraction patterns of samples untreated and nitrided for $3 \mathrm{~h}$ at different temperatures.
Moreover, since as the more distant from the $43.7^{\circ}$ (position of substrate (111) reflection), the greater the $\mathrm{N}$ concentration in the corresponding sample is, it can be said that Figure 5a, b show that if the temperature increases from 350 to $450{ }^{\circ} \mathrm{C}$, the $\mathrm{N}$ concentration increases, for 3 and $5 \mathrm{~h}$.

Secondly, in order to obtain some indications from the $\mathrm{N}$ concentration at a higher depth, let us analyze the expanded austenite (220) reflection, whose $\mathbf{d} \sim 7 \mu \mathrm{m}$, considering a X-ray absorption of $99 \%$, as before ${ }^{19}$. For this purpose, Figure 6 compares the presence of the substrate (220) line, for the samples nitrided for $3 \mathrm{~h}$. Even though the statistics is not so good at this peak, it is sufficient to indicate an interesting aspect: for $350{ }^{\circ} \mathrm{C}$, whose $\mathbf{d} / \mathbf{t}=9.09$, practically there is no broad peak at $2 \theta<74.8$, which is the position of the substrate (220) line, while for $400^{\circ} \mathrm{C}$, whose $\mathbf{d} / \mathbf{t}=2.41$, there are both: the substrate line and the broad peak, centered at approximately $2 \theta=71^{\circ}$. On the other hand, only this broad peak is present for $450{ }^{\circ} \mathrm{C}$, where $\mathbf{d} / \mathbf{t}=0.92$ and is centered at approximately $2 \theta=69^{\circ}$. Therefore, the last sample presents a larger $\mathrm{N}$ concentration of the expanded austenite than the both samples treated at lower temperatures.

Therefore, it can be observed that these comparisons show evidence of the clear consistency between the X-Ray depths $\mathbf{d}$ and the nitrided layer thicknesses $\mathbf{t}$.

\subsection{Citotoxicity measurements}

The cell viability determinations of all the samples are very similar. The curves obtained for untreated and nitrided at $350{ }^{\circ} \mathrm{C}$ are shown in Figure 7. All the samples did not present any toxicity effect similar to the negative control $\left(\mathrm{IC}_{50}>100\right)$, showing their harmless character. The cytotoxicity test in the biological evaluation is a toxicological screening test that can predict the biocompatibility of $316 \mathrm{~L}$

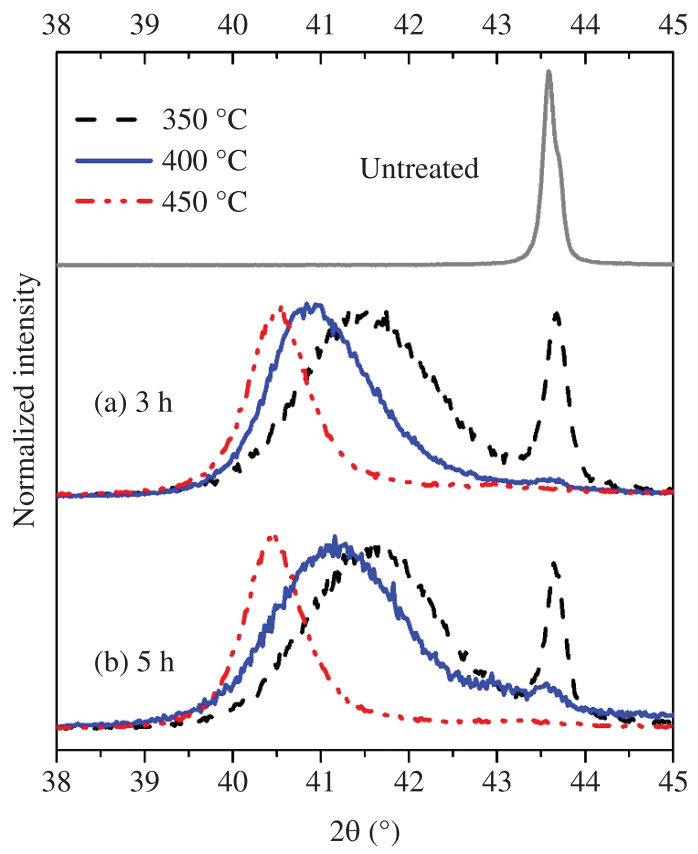

Figure 5. Zoom of the (111) reflection of samples nitrided at different temperatures for (a) $3 \mathrm{~h}$ and (b) $5 \mathrm{~h}$. 


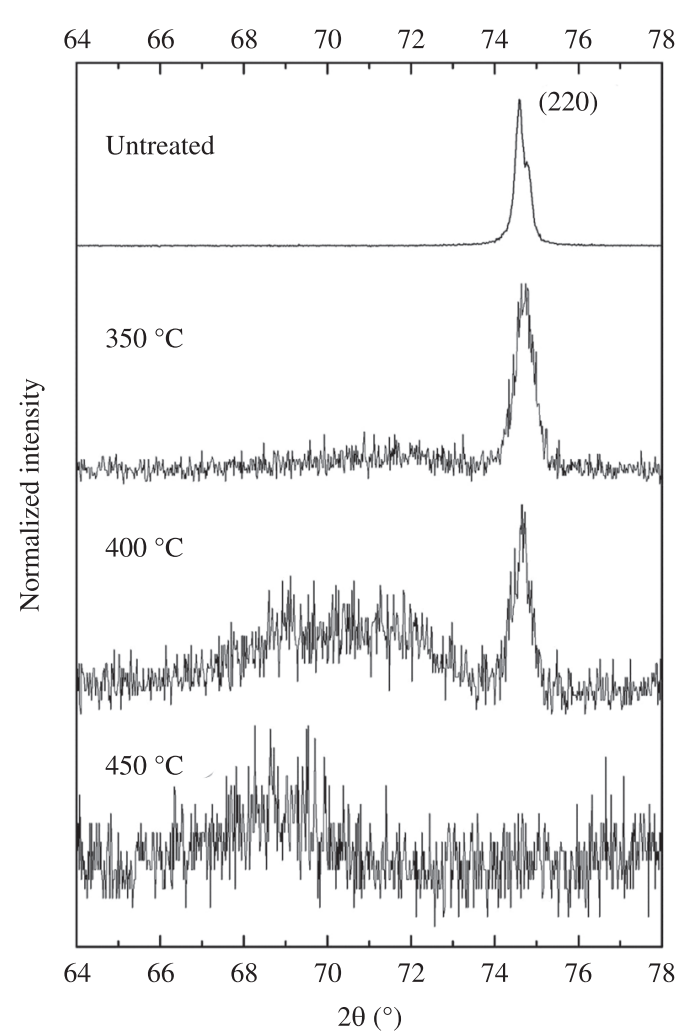

Figure 6. Zoom of the (220) reflection of samples nitrided for $3 \mathrm{~h}$, at different temperatures.

stainless steel, if nitrided or not. This is a primary indication of their potential use for biomedical applications.

\section{Conclusion}

The purpose of the current paper was to correlate the nitrided layer thickness $\mathbf{t}$ of a set of six samples with: i) The penetration depth of the indenter Vickers for two different load (3.6 gf and $50 \mathrm{gf}$ ); ii) Two different penetration depths (approximately 4 and $7 \mu \mathrm{m}$ ) of the X-ray. The results of this investigation show that:

\section{References}

1. Geetha M, Singh AK, Asokamani R and Gogia AK. Ti based biomaterials, the ultimate choice for orthopaedic implants- A review. Progress in Materials Science. 2009; 54:397-425. http:// dx.doi.org/10.1016/j.pmatsci.2008.06.004

2. Lei MK and Zhu XM. In vitro corrosion resistance of plasma source ion nitrided austenitic stainless steels. Biomaterials. 2001; 22:641-647. http://dx.doi.org/10.1016/ S0142-9612(00)00226-X

3. Antunes RA, Rodas ACD, Lima NB, Higa OZ and Costa I. Study of the corrosion resistance and in vitro biocompatibility of PVD TiCN-coated AISI 316L austenitic stainless steel for orthopedic applications. Surface and Coatings Technology. 2010; 205:2074-2081. http://dx.doi.org/10.1016/j. surfcoat.2010.08.101

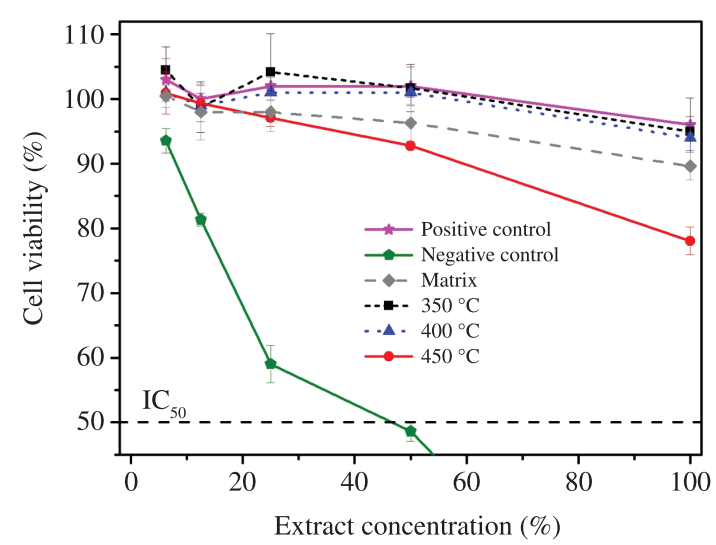

Figure 7. Cell viability of positive and negative control in detail; samples untreated and nitrided at 350,400 and $450^{\circ} \mathrm{C}$.

- The 3.6 gf load was suitable to measure the real hardness of four of the nitrided layers, which show $\mathbf{t} \geq 2.9 \mu \mathrm{m}$. On the other hand, the 50 gf load measures a substrate contribution, probably even for the highest t, $11 \mu \mathrm{m}$

- Analyzing different reflections of X-ray patterns showed that if the layer thickness is lower than the penetration depth of X-rays two phases (austenite and expanded substrate) are present. On the other hand, if the layer thickness is higher, only the austenite is present;

- Moreover, concerning citotoxicity, all the samples, nitrided or not, were approved in the first test for biocompatibility, indicating their potential use for biomedical applications.

\section{Acknowledgements}

We would like to thank Dr. J. M. D. A. Rollo and Leandro J. de Paula for support in the hardness measurements and Dr. Solange de Souza for her interest in the citotoxicity measurements. Moreover, we are grateful to the technical collaborator Natália A. Zanardi. This work was partly supported by the Brazilian research funding agencies FAPESP and CAPES.

4. Bordji K, Jouzeau J-Y, Mainard D, Payan E, Delagoutte J-P and Netter P. Evaluation of the effect of three surface treatments on the biocompatibility of $316 \mathrm{~L}$ stainless steel using human differentiated cells. Biomaterials. 1996; 17:491-500. http:// dx.doi.org/10.1016/0142-9612(96)82723-2

5. Li G-J, Peng Q, Li C, Wang Y, Gao J, Chen S-Y et al. Effect of DC plasma nitriding temperature on microstructure and dry-sliding wear properties of $316 \mathrm{~L}$ stainlesssteel. Surface and Coatings Technology. 2008; 202:2749-2754. http://dx.doi. org/10.1016/j.surfcoat.2007.10.002

6. Nosei L, Avalos M, Gómez BJ, Nachez L and Feugeas J. Stability under temperature of expanded austenite developed on stainless steel AISI $316 \mathrm{~L}$ by ion nitriding. Thin Solid Films. 2004; 468:134-141. http://dx.doi.org/10.1016/j. tsf.2004.06.094

7. Olzon-Dionysio M, De Souza SD, Basso RLO and De Souza S. Application of Mössbauer spectroscopy to the 
study of corrosion resistance in $\mathrm{NaCl}$ solution of plasma nitrided AISI 316L stainless steel. Surface and Coatings Technology. 2008; 202:3607-3614. http://dx.doi.org/10.1016/j. surfcoat.2007.12.040

8. Nosei L, Farina S, Ávalos M, Náchez L, Gómez BJ and Feugeas J. Corrosion behavior of ion nitrided AISI 316L stainless steel. Thin Solid Films. 2008; 516:1044-1050. http://dx.doi. org/10.1016/j.tsf.2007.08.072

9. Kuczynska-Wydorska M and Flis J. Corrosion and passivation of low-temperature nitrided AISI 304L and 316 stainless steels in acidified sodium sulphate solution. Corrosion Science. 2008; 50:523-533. http://dx.doi.org/10.1016/j. corsci.2007.07.003

10. Gontijo LC, Machado R, Kuri SE, Casteletti LC and Nascente PAP. Corrosion resistance of the layers formed on the surface of plasma-nitrided AISI 304L steel. Thin Solid Films. 2006; 515:1093-1096. http://dx.doi.org/10.1016/j. tsf.2006.07.075

11. Borgioli F, Fossati A, Galvanetto E, Bacci T and Pradelli G. Glow-discharge nitriding of AISI 316L austenitic stainless steel: influence of treatment time. Surface and Coatings Technology. 2006; 200:3511-5513. http://dx.doi.org/10.1016/j. surfcoat.2005.07.073

12. Fossati A, Borgioli F, Galvanetto E and Bacci T. Glowdischarge nitriding of AISI 316L austenitic stainless steel: influence of treatment temperature. Surface and Coatings Technology. 2005; 200:2474-2480. http://dx.doi.org/10.1016/j. surfcoat.2004.07.110

13. Franco AR Jr, Pintaúde G, Sinatora A, Pinedo CE and Tschiptschin AP. The Use of a Vickers Indenter in Depth Sensing Indentation for Measuring Elastic Modulus and Vickers
Hardness. Materials Research. 2004; 7:483-491. http://dx.doi. org/10.1590/S1516-14392004000300018

14. International Organization for Standardization - ISO ISO 10993-5: Biological testing of medical and dental materials devices-part 5: tests for cytotoxicity: in vitro methods. Switzerland; 2009.

15. Rodas ACD, Maizato MJS, Leiner AA, Pitombo RNM, Polakiewicz B, Beppu MM et al. Cytotoxicity and Genotoxicity of Bovine Pericardium Preserved in Glycerol. Artificial Organs. 2008; 32:272-276. http://dx.doi.org/10.1111/j.15251594.2008.00542.x

16. Wang L, Xu X, Yu Z and Hei Z. Low pressure plasma arc source ion nitriding of Austenitic stainless steel. Surface and Coatings Technology. 2000; 124:93-96. http://dx.doi.org/10.1016/S02578972(99)00637-4

17. Liu MX, Ma F, Huang P, Zhang JM and Xu KW. Scale dependent plastic deformation of nanomultilayers with competitive effects of interphase boundary and grain boundary. Materials Science and Engineering: A. 2008; 477:295-299. http://dx.doi.org/10.1016/j.msea.2007.05.040

18. Blawert C, Kalvelage H, Mordike BL, Collins GA, Short KT, Jirásková $\mathrm{Y}$ et al. Nitrogen and carbon expanded austenite produced by $\mathrm{PI}^{3}$. Surface and Coatings Technology. 2001; 136:181-187. http://dx.doi.org/10.1016/ S0257-8972(00)01050-1

19. Templier C, Stinville JC, Villechaise P, Renault PO, Abrasonis $\mathrm{G}$, Rivière JP et al. On lattice plane rotation and crystallographic structure of the expanded austenite in plasma nitride AISI 316L steel. Surface and Coatings Technology. 2010; 204:2551-2558. http://dx.doi.org/10.1016/j.surfcoat.2010.01.041 